\title{
Effects of Maternal Ageing on Developmental Defects in Mice
}

\author{
Masaharu Yamamoto and Gen-ichi Watanabe \\ Department of Hygiene and Preventive Medicine, Niigata University School of Medicine, Niigata
}

Greenwood et al." used the expression, "experimental epidemiology" for the laboratory study on animal diseases analogous to human complaints. A controlled experiment in which one variable is manipulated is essential in order to test a hypothesis of disease etiology. An animal model of human diseases has been used extensively in order to discover the mechanism that spreads infectious diseases. In more recent times a major problem of experimental epidemiology is not only in infectious diseases, but also in non-infectious chronic ones, even including developmental defects. ${ }^{2)}$

The risk of occurrence of chromosome anomalies, particularly those in Down syndrome, increases as a woman reaches the later years of reproductive life. This is interpreted as due to increased chromosomal non-disjunction in aged oocytes. ${ }^{3)}$ It is therefore of interest to examine the frequency of chromosome anomalies in embryos of aged animals. If such a maternal dependence could be established in experimental animals, it may be possible to distinguish extrinsic effects on chromosomal non-disjunction from intrinsic factors of ageing in order to investigate the etiology of Down syndrome more closely.

Several attempts have been made to learn whether there is a correlation between incidence of chromosome anomalies and maternal aging in animals. Goodlin ${ }^{4}$ reported no increased aneuploidy in newborns of aged mice. Recently Yamamoto et al. ${ }^{5)}$ reported a high incidence of chromosome anomalies in embryos of aged mice by employing an improved method for cytogenetic analysis during midgestation. This paper deals with consecutive chromosome analyses of embryos of female mice 2-16 months old.

\section{MAterials AND MethodS}

Animals used were 2-16 months old virgin CF\# 1 mice from a colony that has been maintained by random breeding for more than 11 years in this laboratory. Females were caged overnight with proved-fertile males from the same colony and the morning when a vaginal plug was found was designated as day 0.5 of gestation. The animal room temperature and humidity were kept at $23^{\circ} \pm 5^{\circ} \mathrm{C}$ and $60 \pm 10 \%$, respectively. The animals received Crea laboratory chow and water ad libitum. In order to evaluate reproductive capacity and incidence of chromosome anomalies mated females were classified into 4 age groups, (1) $2-4$, (2) 5-8, (3) 9-12, and (4) 13-16 months old. Pregnant mice were killed by cervical dislocation on day 10.5 of gestation and laparotomized. Corpora lutea and products of conception, such as implantation sites and resorbed and live embryos, were counted. Embryos taken from the uterus were placed in normal saline, examined under a dissecting microscope, and crown-rump length measured.

Chromosomes were analyzed by means of a modification ${ }^{6)}$ of Wróblewska and Dyban's method. ${ }^{7)}$ It was not necessary to employ colchicine treatment and in vitro culture in order to accumulate metaphase cells because of active cell proliferation. Slides were stained with Giemsa and mounted. Some 20-40 metaphase plates of good quality were counted for each embryo. When most counts deviated from the normal diploid number 40, an attempt was 
made to distinguish extra or lost chromosomes in restained preparations by means of the band-staining technique. ${ }^{8)}$

\section{RESULTS}

The data in table 1 show that reproductive performance declined with advancing age. The pregnancy rates determined by the presence of more than one live embryo, were 80.0 , $72.7,55.3$, and $33.9 \%$ in $2-4,5-8,9-12$, and $13-16$ months old groups respectively. This decrease was statistically significant $(P<0.001)$ by the ordered chi-square test. ${ }^{9)}$ The mean ovulation rates based on corpora lutea counts of the 2 older groups were significantly smaller than that of the 2 youngest ones, although the difference between the 9-12 and 13-16 months old mice was not significant (table 1 ).

In contrast to the mildly decreased ovulation rate after 9 months of age, the number of implantation sites and live embryos rapidly declined as maternal age progressed (fig. 1). A

Table 1. Reproductive Performances of Mice of Various Ages on Day 10.5 of Gestation

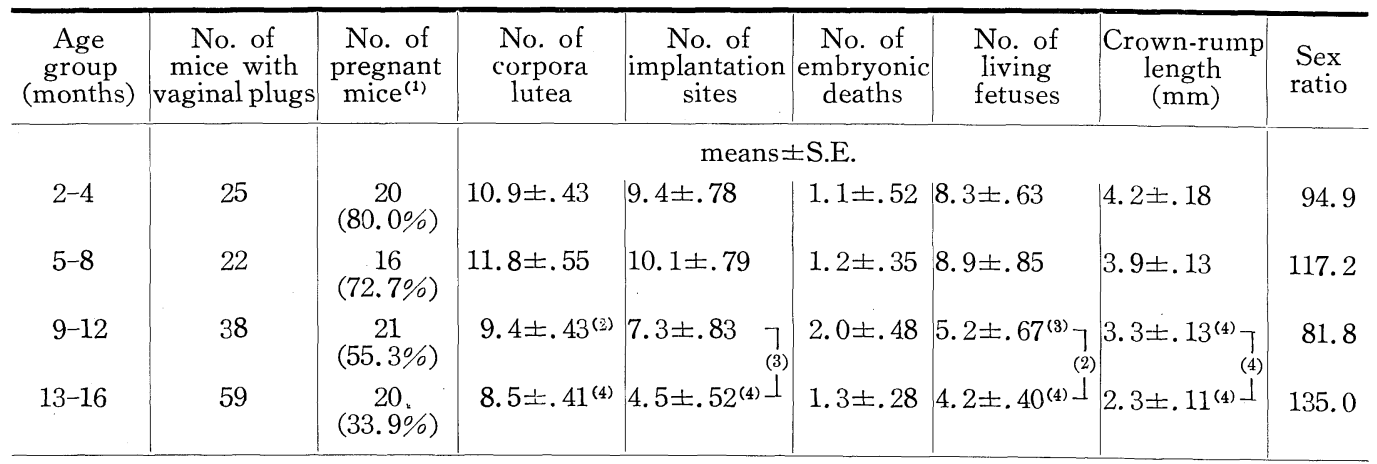

(1) the decreased pregnancy rate was statistically significant $\left(P<0.001\right.$ by the ordered $X^{2}$ test).

(2) $P<0.05$, (3) $P<0.001$, (4) $P<0.0001$ in comparison with the youngest group in each column.

Table 2. Cytogenetic Analysis of Mouse Embryos on Day 10.5 of Gestation

\begin{tabular}{|c|c|c|c|c|c|}
\hline \multirow{2}{*}{$\begin{array}{l}\text { Age group } \\
\text { (months) }\end{array}$} & \multirow{2}{*}{$\begin{array}{l}\text { No. of } \\
\text { mice used }\end{array}$} & \multirow{2}{*}{$\begin{array}{l}\text { No. of embryos } \\
\text { analyzed }\end{array}$} & \multicolumn{3}{|c|}{ No. of embryos with } \\
\hline & & & triploidy & & aneuploidy (2) \\
\hline $2-4$ & 20 & 160 & $\begin{array}{c}2^{(1)} \\
(1.3 \%)\end{array}$ & $\begin{array}{c}2^{(1)} \\
(1.3 \%)\end{array}$ & $2:$ mosaicism $(39 / 40)$ \\
\hline $5-8$ & 16 & 128 & $\begin{array}{l}1 \\
(0.8 \%)\end{array}$ & $\begin{array}{c}1 \\
(0.8 \%)\end{array}$ & 1: trisomy \\
\hline $9-12$ & 21 & 106 & $(0.9 \%)$ & $\begin{array}{c}5 \\
(4.7 \%)\end{array}$ & $\begin{array}{l}3: \text { mosaicism }(39 / 40) \\
2: \text { trisomy }\end{array}$ \\
\hline $13-16$ & 20 & 52 & 0 & $\begin{array}{l}2+3^{(1)} \\
(9.6 \%)\end{array}$ & $\begin{array}{l}\text { 1: monosomy } \\
3: \text { mosaicism } 2(39 / 40 / 41) \\
1: \text { trisomy } 1(40 / 41)\end{array}$ \\
\hline
\end{tabular}

(1) littermates

(2) Significance levels of incidence of aneuploidy:

between 2-4 months and 9-12 months old groups, $P=0.092$ (not significant);

between 2-4 months and 13-16 months old groups, $P=0.011$;

between 5-8 months and 9-12 months old groups, $P=0.069$ (not significant);

between 5-8 months and 13-16 months old groups, $P=0.0082$;

between 9-12 months and 13-16 months old groups, $P=0.20$ (not significant). 


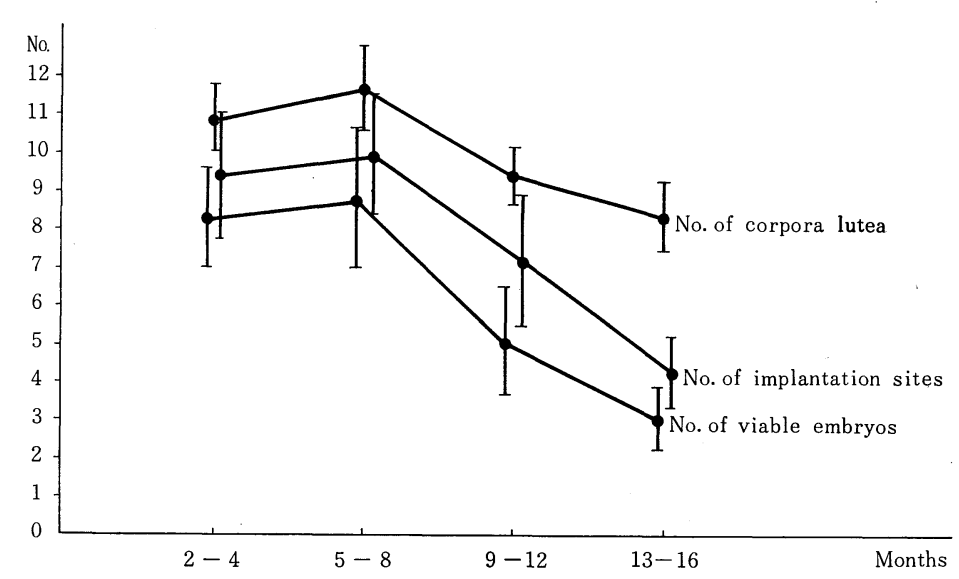

Fig. 1 Reproductive Performances with Advancing Maternal Age (Vertical bars represent the $\mathbf{9 5} \%$ confidence limits)

similar reduction also occurred in the embryonic crown-rump length. Particularly in the oldest group, embryos were uniformly small, as compared with the variable sizes in the younger groups. Ten days after copulation an increase of embryonic deaths was not noted in relation to maternal age. The total number of late embryonic deaths was based on the lack of heart-beat.

Results of the cytogenetic examination are summarized in table 2 and figure 2. A majority of the embryos recovered were examined. Aneuploidy and polyploidy were recorded separately, because different mechanisms seem responsible for the formation of these anomalies.

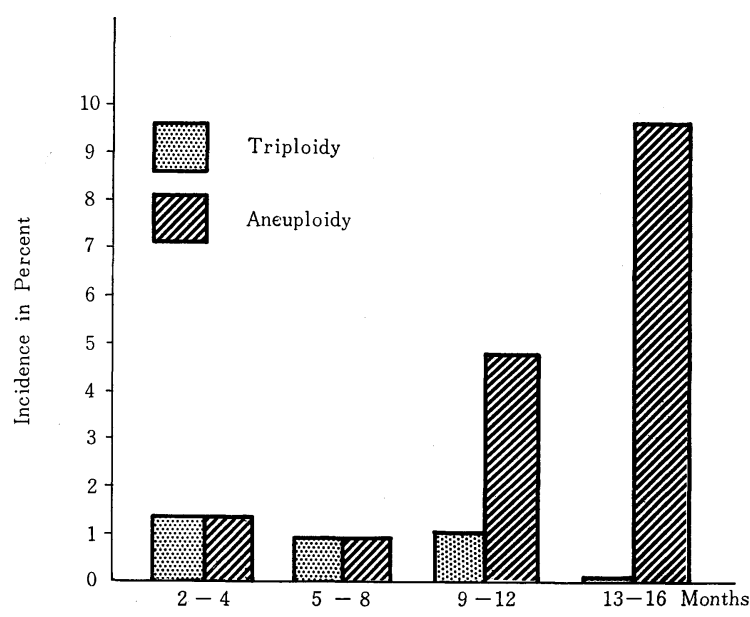

Fig. 2 Increased Incidence of Aneuploidy in Embryos with Advancing Maternal Age

The findings show that aneuploidy increased with advancing maternal age (fig. 2). The gradient became clear when a statistical comparison was made among four age groups. As shown in table 2 statistical differences in incidence of aneuploidy were noted between the 2-4 and 13-16 months old groups $(P=0.011)$ and between the 5-8 and 13-16 months old groups $(P=0.0082)$ by Fisher's test.

Of the 13 embryos with aneuploidy, 8 wers mosaics: 5 with $39 / 40$ in the $2-4$ and $9-12$ groups, 2 with $39 / 40 / 41$ and 1 with $40 / 41$ mosaicisms in the $13-16$ months old group. It is of interest that 2-39/40 mosaics from the youngest group and the 2 mosaics (40/41 and $39 / 40 / 41$ ) and the trisomic from the oldest group were litter mates.

The case of trisomy in the 5-8 months old group was revealed as being the 41 , XXY by means of the trypsin-Giemsa banding technique. The monosomic case in the 13-16 months old group showed a karyotype of 39, XO. Thus, sex chromosomes were involved in both cases. Others were not successfully analyzed in time-passed materials. 


\section{DISCUSSION}

The maternal age dependence of chromosome anomalies has not previously been conclusively demonstrated in animal experiments. One possible reason for this failure is that chromosomally anomalous ova, embryos and fetuses may be eliminated in the course of pregnancy and not be present at birth. Partly to preclude this possibility, an early stage of organogenesis day 10.5 of gestation was chosen for chromosome analysis. This particular stage also gives an adequate number of cells for establishing the chromosomal constitution in each individual. However the frequency of chromosome anomalies at midgestation may still be different from that at fertilization, because of possible elimination of chromosomally aberrant ova and early embryos ${ }^{10)}$ and a litter size reduction in aged mice ${ }^{11}$ )

Although an unusually high incidence of mosaic embryos was found in the present study, assessment of mosaicism should be undertaken with great care given especially for mouse chromosomes. A deviation in chromosome number from the mode of 40 may suggest a possibility of mosaicism. But, in the case of hypodiploid cells in contrast to hyperdiploid ones, one should exclude artifacts produced during slide preparation from products of abnormal cell cleavage of preimplantation embryos, otherwise diagnosis of mosaicism seems doubtfull. As the present study did not demonstrate chromosome bands in all of the materials by the trypsin-Giemsa staining techniques, diagnosis was made when series of chromosome counts definitely deviated from the modal number.

Concerning the etiology of aneuploidy (including mosaicism), two possible factors must be taken into consideration. One is the aging of the oocyte in itself, and the other, the role of the deteriorated environment of the aged ovarian tubes and uterus.

In regard to the role of environment of the ovarian tubes and uterus, there may be an influence on cell cleavage of early embryos. This is, mosaic embryos may be produced from normal diploid zygotes under such an environment. As to the origin of mosaicism with trisomy, however, the presence of trisomic oocytes at fertilization may be more liable to the later formation. In the present study two mosaic and one pure trisomic embryos were found as litter mates. It is interpreted that a trisomic zygote has a greater tendency towards anaphase lagging or non-disjunction as compared with normal ones, as suggested by Richards. ${ }^{12)}$

Jones and $\mathrm{Krohn}^{13)}$ suggested that senescent changes in connective tissue and stroma of the reproductive tract may interfere with a normal passage of sperm, which cause a delay in the time of fertilization. In their work, however, no cytogenetic analysis was undertaken in aged oocytes. If delayed fertilization was operating, a significantly greater number of triploids would be expected in embryos from the older aged mice, as reported by Vickers. ${ }^{14)}$ But this was not found in the present study. The delay in fertilization was, therefore, not sufficient to induce chromosome anomalies in the second meiotic division. Subsequently it is of interest to speculate about the origin of non-disjunction in the first meiotic division. But no experimental data support this assumption so far.

It is safe at present to say that both intrinsic changes of oocytes and environment are involved in the increase of aneuploid formations with advancing the age of mothers.

\section{SUMMARY}

In relation to maternal age reproductive performance and embryonic chromosome constitution were investigated in $C F \# 1$ mice. Decreased pregnancy rate and litter-size reduction occurred with advancing maternal age. Among 446 day-10.5 embryos obtained from 77 pregnant females aged 2-16 months old, $13(2.9 \%)$ had aneuploidy and $4(0.9 \%)$ triploidy, respectively. 
An increase of aneuploidy was found with advancing maternal age, but the production of triploidy was not related to maternal age.

\title{
REFERENCES
}

1) Greenwood, M., Hill, A. B., Topley, W. W. C. and Wilson, J.: Experimental epidemiology, Med. Res. Council, Special Report Series No. 209, His Majesty's Office, London (1936).

2) Watanabe, G.: Experimental epidemiology, Saishin Igaku, 26, 1852-1858 (1971).

3) Edwards, R. G. and Fowler, R. E.: In "Modern Trends in Human Genetics, Vol. I" (Editor: A. E. H. Emery), p. 181-213, Butterworths, London. (1970).

4) Goodlin, R. C.: Non-disjunction and maternal age in the mouse, J. Reprod. Fert., 9, 355-356 (1965).

5) Yamamoto, M., Endo, A. and Watanbe, G.: Maternal age dependence of chromosome anomalies, Nature New Biology, 241, 141-142 (1973).

6) Ingalls, T. H. and Yamamoto, M.: Hypoxia as a chromosomal mutagen: triploidy and tetraploidy in the hamster embryo, Arch. Environ. Health, 24, 305-315 (1972).

7) Wróblewska, J. and Dyban, A. P.: Chromosome preparations from mouse embryos during early organogenesis: dissociation after fixation followed by air drying, Stain Tech., 44, 147-150 (1969).

8) Nesbitt, M. N. and Francke, U.: A system of nomenclature for band patterns of mouse chromosomes, chromosoma, 41, 145-158 (1973).

9) Armitage, P.: Tests for linear trends in proportions and frequencies, Biometrics, 11, 375-386 (1955).

10) Russell, L. B.: Chromosome aberrations in experimental mammals, Prog. Med. Genet., 2, 230-294 (1962).

11) Talbert, G. B.: Effects of maternal age on postimplantation reproductive failure in mice, J. Reprod. Fert., 24, 449-452 (1971).

12) Richards, B. W.: Mosaic mongolism, J. Ment. Defic. Res., 13, 66-83 (1969).

13) Jones, E. C. and Krohn, P. L.: The relationship between age, numbers of oocytes and fertility in virgin and multiparous mice, J. Endocrinol., 21, 469-494 (1961).

14) Vickers, A. D.: Delayed fertilization and chromosomal anomamlies in mouse embryos, J. Reprod. Fert., 20, 69-76 (1969).

\section{マウスの加令に伴う生殖生理学的変化について}

\author{
山本 正治・渡辺厳 \\ 新潟大学医学部衛生学教室
}

マウスの加令に伴う生殖生理学的変化及び胎仔の染色体不分離現象について観察した。実験にはCF \#1 系雌 マウスを用い，乙の動物集団を生後2４カ月，5～8力月，9１2力月，13〜16力月の 4 群に区分した。乙の間雌 マウスを若年成熟雄とつがえた。妊娠 10.5 日に母獣を開腹しその生殖生理学的変化（妊娠の有無, 排卵数, 吸収 胚数, 生存胎仔数など）及び胎仔の染色体構成について検索した。

母獣の加令に伴う妊娠率の低下，排卵数および生存胎仔数の減少をみとめた。胎仔の染色体異常発生の頻度 は，異数性異常については生後2〜4力月，5８力月，9１2力月，13〜16力月群でそれぞれ160例中 2 例 (1.3\%)， 128 例中 1 例 $(0.8 \%) ， 106$ 例中 5 例 $(4.7 \%) ， 52$ 例中 5 例 $(9.6 \%)$ と加令に伴(増加傾向を示した。乙れに反し，倍 数性異常 (3 倍体) の発生は, それぞれ 2 例 $(1.3 \%), 1$ 例 $(0.8 \%), 1$ 例 $(0.9 \%), 0$ 例 $(0.0 \%)$ であり加令に伴う 増加傾向を認めなかった。 